\title{
Binary Oppositions in the Structure of Masnavi Stories
}

\author{
Alimorad Ahmadi \\ Department of English Language and Literature, Islamic Azad University, Kermanshah Branch, Iran \\ Mansour Neurouzi Mostaali \\ Department of Persian Literature, Islamic Azad University, Kermanshah Branch, Iran \\ Faramarz Piri \\ Islamic Azad University-Kermanshah Branch, Iran \\ Mandana Rahimi Bajelani \\ Language and Linguistics Dept, Faculty of Humanities, University of Kurdistan, Iran
}

\begin{abstract}
Structuralism and post-structuralism criticisms are scientific, novel methods of studying Persian stories through which the coherent structure which is intertwined in the story can be revealed. Binary oppositions are basic concepts which exist in structural and post-structural criticism. According to these theories, there are two major functions for the text that advance the story. These binary oppositions can be found in all parts of Masnavi. The authors tried, in this study, first to analyze the lexical meanings of binary oppositions and then to examine the binary oppositions in Masnavi.
\end{abstract}

Index Terms-Molana, Masnavi, binary oppositions, structuralism, post-structuralism

\section{INTRODUCTION}

The structuralism theory, as one of the most significant theories in the twentieth century, has been an active area in all fields of humanities in general, and in literature, anthropology, and linguistics, in particular. It has been an appealing, efficient, and popular style in the analytic criticism. This style was first created from the linguistic viewpoints of Ferdinand De Saucer about the general rules of the language and their discovery through synchronic study, and was applied, then, to other fields as well (Meghdadi, 2000).

In structural analyses, there are two major styles derived from Saussure theories about syntagmatic and paradigmatic pivots (Propp, 1990).Sequential structural analyses are Propp's structural style which has been formed based on the sequence of events; a term derived from syntax. On the other hand, Strauss's style is called vertical analysis which is a concept derived from the vertical analysis of the language (ibid).

According to Strauss, synchronic structural analysis merely shows the obvious side of the text, whereas in diachronic analysis, the 'hidden side' of the story is indicated (ibid).

There are some points to be taken into account in structural analysis:

- Extracting the components of the text

- Discovering the relationships among the components

- Indicating an implication within the generality of the text (Goldman, 1991)

According to Strauss, structure includes some characteristics:

A: It is like a system in which a change in each part would result in change in other parts as well

B: Every structure can be changed into a frequent structure of its type

C: In the light of the above feature, it can be predicted that if there are changes in one or more elements of the structural elements, the whole structure would react (Azad Barmaki, 2003).

\section{A. Binary Oppositions in Criticism}

One of the most important applications in structural and post-structural criticism is binary opposition in which the essence of everything is revealed through opposition with another thing that has no quality at all, and the perception of every subcategory is related to its distinction with another object. This kind of distinction is interpreted as opposition. Our knowledge about things depends on our knowledge about what is in opposition with them. (Caddon, 1999)

Strauss's investigation about cooking is based on oppositions such as raw and cooked, fresh and rotten, and rare and well-done. Such relationships do not reflect the fact which is imposed on the mind, but reflect the structures that encourage the human mind fundamentally to rank its world. Structure and meaning exist, but there are no compatibility necessarily. Strauss believed that, behind all cultural activities, we can find a deep structure in binary oppositions 
which reflect the general structure of the human mind (Dan, 2005). Zimel considers the binary oppositions as a solution to the oppositions in order to achieve the planned integrity (Azad Barmaki, 2003).

Whitehead asserts that the world is binary because, in the deepest meaning possible, it is both transient and eternal. The universe is binary because every fact is both material and mental. The universe is binary because each of its facts necessitates analysis. It is binary for, in every event, the formal pursuit and unity is unified with the objective's independence. The world is infinite because it should be ideally analyzed into various ultimate facts or as Descartes states "into various facts". The universe is unique because of its single appearance and totality. Thus, there is an opposition between infiniteness and unity. Throughout the world, the unity of the mutual affairs is predominant and this results in opposition (Whitehead, 1993).

Ghazali, in Meshkatol Anvar, suggests that if darkness and devil have not appeared, we would not have been aware of light. The realization of deficiency is the first step toward perfection (Ghazali, 2011). The trace of binary oppositions can be found in the majority of the structuralists' viewpoints, especially among narratalogists. According to Roland Barthes, the most fundamental concept for structuralism is binary opposition (Barthes, 1992).

\section{B. Binary Oppositions in Post-structuralism}

Post-structuralism, especially Derrida's deconstructionism which is part of post-structuralism, plays a critical role and is considered a key concept. The difference, however, is that it has been looked upon critically. Derrida, using structuralism against self-structuralism, takes the western binary oppositions (i.e. speech, self, life, father, and light against writing, body, death, mother, and darkness) and deconstruct them without reaching a higher synthesis. He indicates how these binary oppositions result in closures or puzzles that should be tolerated in an unending experience other than overcoming them (Dan, 2003). Basically, Derrida, in his deconstruction, believes in subverting hierarchies and bases in binary oppositions (Meghdadi, 2000). With major changes Jacques Derrida (born in 1930) made in Western discipline in 1960s, the concept of binary oppositions underwent a fundamental change as well (ibid).

Post-structuralists partially criticized the rules that structuralists had firmly proposed for binary oppositions and this is a better reason for its centrism. Now, adopting Strauss and Barthes, we examine the binary oppositions governing the structure of Masnavi stories.

\section{Opposition of soul/self}

Rumi, in the beautiful story of "the king and the handmaiden", bases the story on the binary opposition of soul/self. The center of Rumi's attention is demonstrating the two sides of opposition in the real context. The acting of the characters of the story and the events concerning the binary opposition of soul/self occurs quite artistically. The king is enchanted by a bondwoman. But, it in a short time, the handmaiden gets sick and the king summons all the skilled doctors, who are dependent on their wisdom and knowledge and create another kind of opposition with spiritual doctor to treat the handmaiden, while they ignore the ordinance of the Almighty. However, the more they try, the more the patient gets worse. When the king gets disappointed with all the natural treatments, he turns to God. While he is praying, he falls asleep and he is called in the dream that the skilled spiritual doctor comes to you and cures the handmaiden The spiritual doctor declares the cause of the disease is that the she is in love with a goldsmith in Samarkand. He summons the goldsmith and arranges their marriage. They live happily with each other for six months. Then, the spiritual doctor, by God's order, gives a deadly poison the goldsmith by which the beauty and appeal of the merchant diminishes and gradually he loses his appeal to her. Rumi's interpretation of this story is that, the king is the symbol of the soul. The proud doctors are the symbol of minor wisdom, the handmaiden is the symbol of beastly desires, the goldsmith is the symbol of the world, and the spiritual doctor represents general wisdom or real mentor. By taking a look at the characters of the story, it can be observed that what is fixed in the mind of the reader is the soul/self hierarchy that Rumi criticizes its existence in the human being and summons the audience to accompany.

In olden time there was a king to whom belonged the power temporal and also the spiritual

It chanced that one day he rode with his courtiers to the chase

On the king's highway the king espied a handmaiden: the soul of the king was enthralled by her

(Masnavi, book I, p. 35-38)

The king gathered the physicians together from left and right and said to them, "the life of us both is in your hands"

My life is of no account, she is the life of my life, I am in pain and wounded: she is my remedy

(ibid, p. 43-44)

When the king saw the hopelessness of the physicians, he ran bare-footed to the mosque

He entered the mosque and advanced to the altar, the prayer carpet was bathed in the king's tear

(ibid, p. 55-56)

TABLE1.

BINARY OPPOSITIONS IN THE CHARACTERS OF THE KING AND THE HANDMAIDEN

\begin{tabular}{|l|l|l|}
\hline King & Sensual skilled doctor & King \\
\hline Goldsmith & Spiritual skilled doctor & handmaiden \\
\hline
\end{tabular}


TABLE2.

BINARY OPPOSITIONS IN THE ADVANCING ELEMENTS OF THE KING AND THE HANDMAIDEN

\begin{tabular}{|l|l|l|l|l|l|l|l|l|}
\hline & & line & & & line & & line \\
\hline Stranger & Self & 146 & Impolite & polite & 78 & Worldliness & Religion & 36 \\
\hline Fear & Safety & 171 & gallant & mean & 90 & Right & Left & 43 \\
\hline untrue & Real & 180 & Man & Woman & 90 & Bile & Laxative & 53 \\
\hline Unruly & Obedient & 181 & Barrenness & Fertility & 104 & Constipation & Laxative & 53 \\
\hline Fire & Water & 199 & This & That & 111 & Fire & Water & 54 \\
\hline Serenity & Depression & 231 & Tongueless & Tongue & 113 & Evident & Hidden & 60 \\
\hline Pageant & Believer & 239 & Heaven & Earth & 127 & Shadow & Sun & War \\
\hline Happiness & Sorrow & 244 & Beginning & End & 143 & Peace & 71 \\
\hline
\end{tabular}

Strauss analyzes the binary oppositions based on the agreement among tensions which gives a more practical existentialism color to it; for example, life and death may be in opposition with each other, but the concept of the life after death can intervene the two opposing issues (Dan, 2005).

Now, if we have a closer examination of the structure of the story of the king and the bondwoman, we can realize that Rumi has used binary opposition to convey his intended meaning to the reader, create the desired reaction in the audience, and direct him to that particular spiritual and moral context. In the king and the bondwoman and its spiritual interpretation, the symbols of self, wisdom, and love are discussed. Three dimensions of competition among lover, beloved, and rival leads to the binary graph and balance between lover and beloved and consequently ends in either the unification of the lover and beloved or their death.

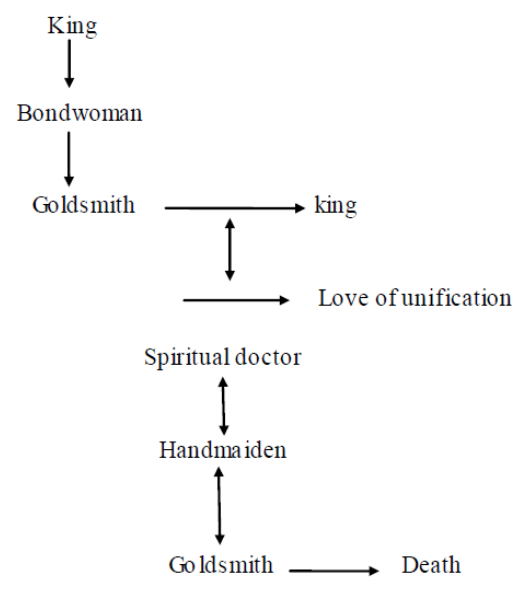

\section{Existence/nonexistence opposition}

The most important opposition which is the basis of every opposition in the realm of creation and developmental world as well as in the world of mind and science is the opposition of existence and nonexistence. The first and the last category of Parmenides philosophy is existence category. It states that whatever exists has existence and whatever does not exist is not created. Existence does not vanish and non-existence does not come to life. Whatever exists will be quiet and easy in the world and will not change (Jones, 1970). Rumi is one of the Sufis that has used non-existence in opposition with existence. He has conveyed his theosophical and moral intentions in a line using binary oppositions:

Life is the peace of contraries, death is the fact that arose between them

(Zamani, 2009, p. 1293)

That which seems to be really existent is (mere) skin, while that which seems to have perished - is the root.

(Nickolson, 1996, p. 1668)

We and our existence are really non-existence: thou art the absolute Being which manifests the perishable

(Zamani, 2009, p. 602)

The form came forth from Formlessness and went back (thither), for verily unto Him are we returning

(ibid, p. 1141)

Being can be seen in not being: the rich bestow generosity on the poor

(ibid, p. 3202)

What is the mirror of being? Not-being. Bring not being (as your gift), if you are not a fool

(ibid, p. 3201)

\section{Figure/sense}

The opposition between figure and sense is one of the pillars of Rumi's doctrines that should be remembered forever. He mentions this opposition in many various topics and contexts and in majority of the figures of speech as well as different symbols. In fact, there is no specific reason for naming the fundamental opposition within the world to the opposition between figure and sense except that these two terms have the widest function from among all pairs of opposition terms that Rumi has used. 
Rumi regards a basic distinction between figure and sense. Figure is the external aspect and sense is the hidden internal fact. Eventually, sense is what is evident to God and since God is beyond every remuneration, in the final analysis, sense is nothing but God. "Shadow which is figure is an indication for sun which is sense".

What is form in the presence of reality? Very feeble. 'tis the reality of the sky that keeps it upside down (like an inverted cup)

The motion of wind is from its reality, like the wheel that is captive to the water of the stream.

(-Masnavi, book I, p. 3330-33)

Know that the outward form passes away, (but) the world of reality remains for ever

How long will you play at loving the shape of the jug? Leave the shape of the jug, go seek the water.

You have seen its outward form, you are unaware of the reality; pick out from the shell a pearl, if you are wise.

(Masnavi, book II, p. 1020-22)

You ask "why art thou doing this?" because the forms are (as) the oil, and the essential meaning is (as) the light.

Otherwise, wherefore is this saying "why"? - the use of this form is only the form itself.

(Masnavi, book IV, p. 2994-95)

Its outward says, 'we are this, and no more'; its inward says, 'look well before and behind!'

Its outward is denying and says that the inward is naught; its inward says, 'we will show (thee the truth), wait and see!'

(Masnavi, book IV, p. 1009-10)

The more perfect he is in worldly science, the more backward he is in reality and the more forward in appearance.

One needs a knowledge whereof the root is Yonder, inasmuch as every branch is a guide to its root.

Why should every wing fly across the breadth of the Sea? Only the esoteric knowledge will bear thee to the presence (of God).

(Masnavi, Book III, p. 1117\&1124-25)

\section{Good/ Evil}

The most evident and annoying opposition existing in the universe is the opposition between Good and Evil. However, the absolute virtue can be found in God. Evil and its various levels are originated from diminishing the light of Goodness due to getting far from the origin. In this world, affairs are relatively not absolute Good or Devil because no absolute quality can exist. Objects and affairs are considered Good or Evil in comparison with us, not compared to God because before God, everything does the same thing; revealing the hidden treasure. Rumi discovers the opposition of virtue and vice and fully understands this point that if there were no Evil in the world, most of the God's epithets such as forgiveness and revenge could not manifest themselves at all.

Hence there is no absolute evil in the world; evil is relative, know this also

In the realm of time there is no poison or sugar that is not a foot (support) to one and a fetter (injury) to another

To one a foot, to another the fetter; to one a poison and to another like a sugar

Snake poisons life to the snake, but it is death in relation to man

The sea is as a garden to the water-creatures; to the creatures of earth it is death and a painful brand

(Masnavi, book IV, p. 65-69)

None of these things is absolutely good, nor is any of them absolutely evil

The usefulness and harm of each depend on the place: for this reason knowledge is necessary and useful

(Masnavi, Book VI, p. 2898-99)

Although thou believe that all the evils are from Him, but it is not a deficit of His grace (God)

Giving evil to man is of His maturity, O Man (Mohtasham), I will show you an example (to prove this)

(Masnavi, Book II, p. 2535-36)

The cadi said, "Were there no bitter Commandment and were there no good and evil and no pebbles and pearls,

And were there no flesh and Devil and passions, and were there no blows and battle and war,

Then by what name and title would the King call His servants, $O$ abandoned man?

How could he say, 'O steadfast one' and 'O forbearing one'? How could He say, 'O brave one' and 'O wise one'?

(Manavi, book VI, 1747-50)

Existence/nonexistence

These two terms are the most complicated oppositions Rumi has used because both terms may or may not refer to figure or sense with regard to the context.

Everyone has turned his face in some direction, but those holy ones have turned towards that which transcends direction.

(Masnavi, Book V, p. 350)

You are of where, but your origin is in Nowhere: shut up this shop open that shop.

(Masnavi, Book II, p. 612)

Form is brought into existence by the Formless, just as smoke is produced by a fire.

(Masnavi, Book VI, p. 3712)

Rumi puts these two views beside each other in a similar literature and in other cases refers to one of them. 
This world of non-existence has become like real existence, while that world of real existence has become very hidden

The dust is on the wind; it is playing, it is making a false show and forming a veil

This which is busy (in appearance), is really idle and a husk, and that which is hidden, is its core and origin

(Masnavi, Book II, p. 1280-83)

\section{Adam/Satan}

One of the primary concepts that human has had opposition with from the beginning of his existence is the opposition between Adam and Satan; an opposition that has existed from the time of human creation up to now. God addresses man in A'raf verse (Quran) in the following way:

"We created you, then we gave you figure, and told the angels to genuflect. All genuflected except Satan. God said "when I ordered you to genuflect what made you disobey?", Satan said "I am better than him; you have made me from fire and him from mud" (A'raf, 7, p. 11-12). Rumi has perfectly stated this opposition in Masnavi.

In an Adam who was without like or equal, the eye of Iblis discerned naught but a piece of clay

(Masnavi, Book III, p. 2759)

See the beginning and the end with both eyes: beware, do not be one-eyed like the accursed Iblis

(Masnavi, Book IV, p. 1709)

Hundreds of thousands of years the accursed Iblis was a saint and the prince of true believers;

On account of the pride which he has, he grappled with Adam and was put to shame like dung at morning tide

(Masnavi, Book I, p. 3296-97)

The sin of Adam arose from the belly and sexual intercourse, and that of Iblis from pride and power.

Consequently, he (Adam) at once besought pardon, while the accursed (Iblis) disdained to repent

(Masnavi, book V5, p. 20-21)

Like Adam whose lapse was temporary, of necessity he showed penitence at once

Since the sin of Iblis was original, for him there was no way to precious penitence

(Masnavi, book IV, p. 3414-15)

Those who are the elect children of Adam sigh forth, 'verily we have done wrong.'

Submit thy petition, do not argue like the accursed hard-faced Iblis

(Masnavi, book IV, p. 347-48)

\section{Man/woman}

The opposition between man and woman is one of the major concepts of binary positions in the world. In theosophical poems of Rumi which revolves around the world's bipolarity, men and women are mainly symbols. Therefore, in the poems of this theosophical scholar, men are the symbol of the saints and women are the symbol of pageants. In other words, men are under the dominance of wisdom and women are overcome by self. Men consider sense whereas women are stuck in figures. Accordingly, men are theosophical devotees and women are after mundane affairs.

This man and wife, which are the flesh and the reason, are very necessary for good and evil;

And this necessary pair in this house of earth is engaged in strife and altercation day and night

The wife is craving requisites for the household, that is to say, reputation and bread and viands and rank

Like the wife, the flesh in order to contrive the means (of gratifying its desires), is at one time seeking humility and at another time to domination

The reason is really unconscious of these worldly thoughts: in its brain is nothing but love of God

(Masnavi, Book I, p. 2618-22)

O you wife beware of your inner self, fear of your kind (woman), since thou hast a share of evil in yourself

(Masnavi, book II, p. 2272)

\section{Love/wisdom}

One of the main oppositions in Rumi's viewpoints is the opposition between love and wisdom. The opposition of love and wisdom plays a critical role in most of the Sufi's works, including Rumi's. However, Rumi's criticisms about wisdom in the eye of love should be extracted from the context of all of his doctrines in which they play a major role, because wisdom is an essential introduction for love as well as directing human toward God.

Partial reason is a denier of Love, though it may give out that it is a confidant

It is clever and knowing, but it is not naught; until the angel has become naught, he is an Ahriman (Devil)

(Masnavi, Book I, p. 1982-83)

Sacrifice your intellect in love for the friend: anyhow, intellects are from the quarter where He is

The intelligent have sent their intellects to that quarter: only the dolt has remained in this quarter where the Beloved is not

If from bewilderment this intellect of yours go out of this head, every head tip of your hair will become a new head and intellect

(Masnavi, Book IV, p. 1424-26)

He (Iblis) had knowledge but since he had not religious love, he beheld in Adam nothing but a figure of clay

(Masnavi, Book VI, p. 260) 
The intelligent are abased before Him from necessity; the lovers are abased with hundredfold free will

The intelligent are bond slaves to Him; the lovers are like sugar and candy to Him

"Come against your will" is the toggle for the intelligent; "come willingly" is the spring-time of them that have lost their hearts

(Masnavi, Book III, p. 4470-72)

Emergence of binary oppositions in some of the stories of Masnavi

By taking a closer look at the precious book of Masnavi, we can come to this important point that binary oppositions have been the essence of Rumi's work. The oppositions such as positive and negative, good and evil, vice and virtue, ... are completely apparent. Rumi has frequently used this effective style to introduce his intended moral and theosophical concepts to the reader. In the following, some of these oppositions are mentioned as examples:

- The story of the Jewish king who killed the Christians (Masnavi, 2009), opposition of good/bad

- The story of the merchant and parrot (Masnavi, 2009), opposition of self/soul

- The story of the witches and Moses (Masnavi, 2009), opposition of good/evil

- The opposition between the Godly dervish who needs God and the dervish who needs others ((Masnavi, 2009), opposition of good/evil

- The opposition of Satan and Quran verses ((Masnavi, 2009), opposition of good/evil

- Spitting of (Amro) on Imam Ali (Masnavi, 2009), opposition between good/evil

- The story of Adam's surprise at Satin's reprimand (Masnavi, 2009), opposition of good/evil

- The story of Jesus' follower and resurrecting the dead (Masnavi, 2009), opposition of doubt/certainty

- The story of the proud king and the saint (Masnavi, 2009), opposition of religion/ worldliness

- The story of Moses and calf worshiper (Masnavi, 2009), opposition of good/evil

- The story of Satan and Moavieh (Masnavi, 2009), opposition of Satan/Man

- The story of the hypocrites and their assisting prophet Muhammad in building mosque (Masnavi, 2009), opposition of good/evil

- The story of the unbelievers and prophets (Masnavi, 2009), opposition of good/evil

- The story of the person who believed God could not catch him while committing a sin and Shoeib's response (Masnavi, 2009), opposition of good/evil

\begin{tabular}{|c|c|c|c|}
\hline Protagonist & Antagonist & Volume & page \\
\hline Christians & Jewish king & 1 & 143 \\
\hline Parrot & Merchant & 1 & 493 \\
\hline Moses & Witches & 1 & 516 \\
\hline Godly Dervish & Worldly Dervish & 1 & 810 \\
\hline God & Satan & 1 & 974 \\
\hline Ali & Amro & 1 & 1059 \\
\hline Adam & Satan & 1 & 1101 \\
\hline Jesus & Suspicious Youth & 2 & 146 \\
\hline King's Hawk & Owls & 2 & 298 \\
\hline Mystic & Proud King & 2 & 380 \\
\hline Moses & Calf Worshippers & 2 & 509 \\
\hline Moavieh & Satan & 2 & 649 \\
\hline Muhammad & Hypocrites & 2 & 737 \\
\hline Prophets & Unbelievers & 2 & 748 \\
\hline True followers & Sinful people & 2 & 825 \\
\hline
\end{tabular}

\section{CONCLUSION}

The theory of binary oppositions has a long history. Its basics can be found in the thought of primitive man. Since Masnavi is a theosophical collection of poems formed based on the opposition between this world and the other world, good and bad, existence and non-existence, contentment and welfare, blasphemy and religion, etc. if we take a closer look at the structure of Masnavi, we can realize that Rumi has used binary oppositions to convey his intended theosophical concepts and create the desired effect in the audience. The binary oppositions such as positive/negative, soul/self, good/bad, etc. are clearly evident in Masnavi. The topics that Rumi has cited in Masnavi are indicative of this issue. Generally, the heroes of the stories have a high-spirited soul and possess features like charity, good sense of humor, and bravery. On the other hand, there is the anti-hero who possesses a devilish and pitiful character which is right against the characteristics of the hero of the story.

In the deep structure of Masnavi, Rumi, in the description of his major basics, creates binary oppositions directly or indirectly. When he is talking about soul/self, he mentions the king and the bondwoman story in which the king is the symbol of soul and the bondwoman is the symbol of self and creates a binary opposition between them. Elsewhere, when he is talking about dipping the anger, he brings the story of Imam Ali and Amro which is indicating the opposition of good/bad. It can be concluded that the general deep structure of these stories is based on the two governing poles in the Islamic culture (i.e. this world and another world) and the concepts are raised according to these 
two pivots. Thus, the situation of story writing in that time and the theosophical basis which revolves around the bipolarity of the universe, has encouraged Rumi to form Masnavi as a rather diverse collection of oppositions and base his intellectual foundation on the spirit of opposition among the characters of the story.

\section{REFERENCES}

[1] Azad Barmaki, Taghi. (2003). Sociology Theories, Soroush Publications, Tehran.

[2] Barthes, Roland. (1968). Elements of Semiology, Hill and Wang:New York.

[3] Cuddon, J.A. (1999). A Dictionary of Literary Terms, 4th edition, London, penguin.

[4] Ghazali, Mohammad bin Mohammad. (2011). Meshkatol Anvar. Mola, Tehran.

[5] Goldmann, Lucien. (1966). Sciences humaines et philosophie. Suivi de structuralisme génétique et création littéraire. Paris: Gonthier.

[6] Holy Quran. (2008). Qom, Alhadi Publications.

[7] Jones, W. T. (1970). The History of Western Philosophy. The Classical Mind, Vol.1, 2nd edition, USA.

[8] Meghdadi, Bahram. (2000). Literary Terms from Plato to the Present. Vol.1. Fekre rooz, Tehran.

[9] Reynold A. Nicholson. (1998). Rumi: Poet and Mystic. England: Oneworld.

[10] Stiver, Dan. (1996). The Philosophy of Religious language, symbol and story, Blackwell.

[11] Propp, Vladímir. (1968). Morphology of the Folktale. (Translation) The American Folklore Society and Indiana University.

[12] Whitehead, N. Alfred. (1933). Adventures of Ideas, New York: New American.

[13] Zamani, Karim .(2000). A Reading of Molana's Masnavi. Vol 7, Etelaat, Tehran.



Alimorad Ahmadi is an instructor at Islamic Azad University, Kermanshah Branch. He was born on 27, Feb. 1973. He has been teaching English language and literature for 12 years. His recent works include translation of three books into Persian: American Politics and Society by David McKay,2012, American All by Peter Kivisto, Wendy,2012, and Essential Economics: A Guide for Business Students by Ken Fergusen,2009. His recent published papers include:

- Barriers to Learning ESP among Iranian University Students, Procedia, Social and Behavioral Sciences, Cyprus International Conference on Educational Research, 2012 • Public Education, Compulsory and Free? A Paradox, Procedia, Social and Behavioral Sciences, Cyprus International Conference on Educational Research, 2012 • Critical Thinking in Higher Education: Unfulfilled Expectations. Brain. Broad Research in Artificial Intelligence and Neuroscience, Vol. 3, Issue 2. 2012

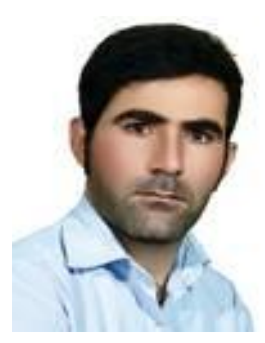

Mansour Neurouzi Mostaali was born in 1984 in Kermanshah. He has M.A. in Persian language and Literature form Razi University, Kermanshah, Iran. At present he is doing some comparative research on Frankfurt School.

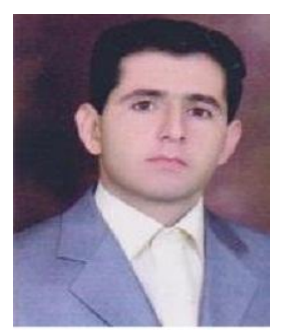

Faramarz Piri received his M.A. in TEFL from University of Isfahan, Iran. He is currently teaching English at Islamic Azad University, Kermanshah branch. His areas of interest include Second Language Acquisition, language teaching methodology, and literature. His recent published papers include:

- The Effect of Negotiation of Meaning on the Accuracy in EFL Writing, Theory and Practice in Language Studies, Vol. 2, No. 5; May 2012 • The Effects of Pre-task, On-line, and both Pre-task and Online Planning on Fluency, Complexity, and Accuracy - The Case of Iranian EFL Learners' Written Production, English Language Teaching, Vol. 5, No. 6; June 2012

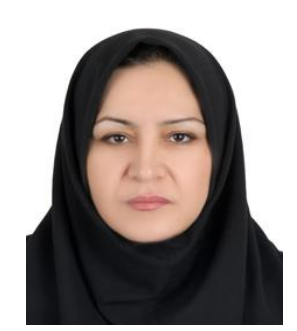

Mandana Rahimi Bajelani is MA student in Language and Linguistics Department, University of Kurdestan. She was born on 23, Sept., 1973 in Kermanshah- Iran. She is currently teaching English in Kermanshah schools. 